Vol. 3, No. 01; 2020

ISSN: 2581-4664

\title{
THE EFFECT OF ORGANIZATION LEARNING, ROLE CONFLICT AND ORGANIZATIONAL CULTURE ON EMPLOYEE PERFORMANCE AND ORGANIZATIONAL PERFORMANCE : STUDY IN DJP ACEH
}

\author{
Marzuki, Nasir and Sofyan Idris \\ Department of Management, UniversitasSyiah Kuala, Indonesia \\ http://doi.org/10.35409/IJBMER.2020.3143
}

\begin{abstract}
The purpose of this research is to test and analyze the effect of organization learning, role conflict and organizational culture on employee performance and its implication on performance. The object is the Regional Directorate of Taxation of Aceh (DJP Aceh). The population is the office employees as much as 120 people, and the sample is taken by the census method, which takes all population member as a sample, so that is as much as 120 as respondents. Data analysis equipment used in this research is Structural Equation Modeling (SEM) with the help of amos program. The results of the study prove that : organization learning has an effect on employee performance, role conflict has an effect on employee performance, organizational culture has an effect on employee performance, organization learning has an effect on organizational performance, role conflict has an effect on employee performance, organizational culture has an effect on organizational performance, organizational culture has an effect on organizational performance, and employee performance has an effect on organizational performance. These all results contribute to enrich the knowledge especially in management. For academic, this research has tested the model and this can be a reference for further research both in developing or making a new ones. The originality lies in the integration of the previous model and the use of SEM as a statistical approach. The limitation lies in the number of variables that are only five, with one object
\end{abstract}

Keyword: Organizational Learning, Role Conflict, Organizational Culture, Employee Performance and Organizational Performance.

\section{INTRODUCTION}

In order to deal with the era of globalization, it is imperative that employees have the integrity, professionalism and high level of accountability so that every job done can always be measured and accountable. An organization is required to have qualified human resources and have the capability to compete both in regional and international forums. The improvement of professional staff is of paramount importance, in the framework of efforts to improve the quality and quality of employees as a whole. Professional employees are basically employees of high quality. 


\section{International Journal of Business Management and Economic Review}

Vol. 3, No. 01; 2020

ISSN: 2581-4664

The Directorate General of Taxes (DJP) is one of the Directorate of the Ministry of Finance who is tasked with collecting taxes from all taxpayers, both taxpayers, private persons and government treasurers, who are in the territory of the Republic of Indonesia. The collected tax revenues will be state revenue and will be used to finance the development of all fields, such as providing education, financing public health services, building roads, seaports, airports, pay civil servants salaries and other state expenditures.

The low performance of the DJP in realizing the targets set out one of the factors is the problem of relatively low staff capability. It can be seen from the constitutional perspective, which is the lack of taxpayer compliance. Then the indication of the still poor performance of the Regional Directorate of Taxation of Aceh (DJP Aceh) is in the Business Process / Perspective conducted, where the ineffective inspection and the low level of tax arrears are liable, then the problem of learning and growth perspective, where the less optimal budget execution and financial perspective the lack of achievement achievement set by the DJP Aceh also affects its capabilities in achieving the targets set.

The phenomenon related to the performance of employees in the DJP Aceh is still inadequate to the standards set by the leadership, this can be seen from the achievement of realization of tax revenue every year. In current tax receipts the reality is not in line with the government's expectations, due to some things such as Taxpayers in paying their tax liabilities not on time and not even a small number of entrepreneurs who do not report their business so that tax revenues can not be maximized, many business entities that have stood up and have carried out business activities. Another problem arises is that there are still many taxpayers' behaviors to minimize their tax payments, which will result in less optimal tax revenues.

The low performance of employees is also strongly influenced by the factors of organizational learning or organization learning which is an organization that empowers all its members to conduct learning activities. The core of the organization learning lies in the ability of the organization to always learn from the changes that occur. All actors involved in the organization are required to always perform improvements and adapt to their environment (Maryam, 2016). Every organization is formed to achieve a certain goal, and when it comes only then it can be said to be successful.

Other factors that influence the improvement of employee performance and organizational performance are role conflicts among employees. Employees are always faced with the role conflict problem in carrying out their duties. Role conflict arises due to the mismatch between the expectations conveyed to individuals within the organization with others inside and outside the organization, this can be seen from the conflict between young employees and senior employees in performing their duties and functions. (Pujaningrum and Sabeni, 2012) have given the limits of conflict as a state of competition that occurs in groups where there is a discrepancy of expectations with one another. While role conflict is a conflict that arises because the organizational bureaucratic control mechanism does not conform to the norms, rules, ethics and professional independence.

Whereas in relation to organizational culture can be explained that organizational culture is also one of the factors determining performance achievement of an employee. The organizational culture in Aceh DJP Office is a manifest manifestation of organizational culture actualization which is a comprehensive program in accelerating efforts in organizing organizational operational activities more efficiently and effectively. Organizational cultural 


\section{International Journal of Business Management and Economic Review}

Vol. 3, No. 01; 2020

ISSN: 2581-4664

aspects are the values that guide human resources to address external issues and integration adjustment efforts into the enterprise, so organizational members are able to understand existing values and how they should act or behave (Swanburg, Ester and Samba, 2000). If the organizational culture goes well it will encourage the emergence of good employee performance.

\section{LITERATURE REVIEW}

\section{Organizational Performance}

Organizational performance is an achievement level indicator that can be achieved and reflects the success of an organization, and is the result of the organization's organizational behavior. Performance can also be said as an output of a particular process performed by all organizational components of the specific sources used (input). Furthermore, performance is also the result of a series of activities that are carried out to achieve the organization's specific goals. For an organization, performance is the result of a cooperative activity among members or organizational components in order to realize organizational goals.

Organizationis a structure of the division of work and the structure of the working relationship between a group of people who hold a particular position to work together to achieve a particular goal. According to (Armosudiro, 2012)the organization is the structure of the division of labor and the structure of the working relationship between a group of people who hold a particular position to work together to achieve a particular goal.

The organization is any form of federation between two or more persons who work together and formally tied in order to achieve a defined purpose in the bond in which a person / a so-called superior and a / a group of persons referred to as subordinates. (Armosudiro, 2012)

The organization is a group of people (two or more) who are formally united in a partnership to achieve the established goals. An organization is in shape because it has the basis and purpose to be achieved. According to (Money, 1996), the organization is a form of human affiliation to achieve common goals. But we need to understand that the foundation of the organization, not the "who" but "what is" means that the notion of who it is Hold the organization, but "whether" the task of the organization.

\section{Employee Performance}

According to (Margiati, 2010), the performance concept is an abbreviation of the work energy kinetics which in English is the performance. Performance or performance is the output produced by functions or individuals on a particular job or profession. Performance often referred to as work achievement is the work of quantity and quality that a person achieves in carrying out his duties according to the responsibilities given at a given time. (Engko, 2008) defined individual performance as an individual working achievement set by standards or criteria set by an organization.

Based on the above understanding, it can be concluded that performance or often referred to as job performance or job performance is the quality and quantity of an individual output in a particular activity and according to the measure applicable to the work concerned. This size is determined by the organization that is designated as a target within a period.

According to (Chairy, 2011) in general performance assessments are the processes in which the organization evaluates the performance or performance of employees with the goal of improving it. (Chaston, Badger and Sadler-Smith, 1999), suggested a performance assessment or 


\section{International Journal of Business Management and Economic Review}

Vol. 3, No. 01; 2020

ISSN: 2581-4664

work performance is a method for evaluating quantitative and qualitative work behaviors at work sites. While (Hanafi and Widiyanti, 2014) defined work performance assessments as manager activities to evaluate employee's work performance behavior and establish further wisdom. Behavior assessment involves assessment of honesty, honesty, leadership, cooperation, loyalty, dedication, and employee participation. Assessment of work performance is assessing the real workflow ratio by the quality and quantity standards generated by each employee.

\section{Organization Learning}

(Gephart et al., 1996) stated that organizational learning is an important element contributing to achieving organizational performance. Organizational learning and learning organizations are essentially a substance, but different. Pedler et al. (2013: 87) said that learning organization can facilitate learning for all its members and continuously reform". (Neefe, 2001) tries to analyze organizational learning definitions and concludes several elements that must exist, namely: The learning process, Knowledge acquisition or generation, Individual Learning, Teams Learning, Organizational knowledge.

Some management experts provide different definitions of organizational learning such as(Hofstede, Hofstede and Minkov, 2010) which defined organizational learning as organizational skills to create, acquire, interpret, transmit and divide knowledge, aiming to modify its behavior to reflect new knowledge and insights.

Another definition by (Stata, 1989) stated that organizational learning takes place through the sharing of insights, knowledge and mental models built on knowledge and past experience. (Khandekar and Sharma, 2005) defined organizational learning as an organization that facilitates learning in all members of its organization and is continuously transforming itself. Organizational learning is the process of acquiring individual and group knowledge that is willing to apply it to their work in making decisions and interacting as dynamic capabilities as a source of competitive advantage (Khandekar and Sharma, 2005).

Then (Argyris and Schon, 1995) revealed that the organization learning is the process of detecting and correcting errors. Organizational learning according to Taylor is an opportunity given to employees so that organizations become more efficient. Then (Hofstede, Hofstede and Minkov, 2010) defined organizational learning as an organization's expertise to create, acquire, interpret, transmit and divide knowledge, aimed at modifying its behavior to illustrate new knowledge and insights.

\section{Role Conflict}

The role here is as stated by (Viator, Dalton and Harp, 2012), a psychological symptom experienced by members of an organization that can cause discomfort in working. The role of an employee is a group of activities that is expected by another party to be executed by the individual in his or her position within the organization concerned.

(Riyanto and Puspa, 1999) has given conflicting boundaries as a state of competition that occurs in groups where there is a mismatch between one's expectation and another. While role conflict is a conflict that arises because the organizational bureaucratic control mechanism does not conform to the norms, rules, ethics and professional independence.

Role theory asserts that individuals will experience role conflicts if there are two or more pressures that occur simultaneously aimed at a person, so if one complies with one of them 


\section{International Journal of Business Management and Economic Review}

Vol. 3, No. 01; 2020

ISSN: 2581-4664

it will be difficult or impossible to comply with the others (Riyanto and Puspa, 1999). According to (Fanani, Hanif and Subroto, 2008), role conflicts are types of conflicts that result from various roles. This conflict occurs because individuals simultaneously play different roles, some have conflicting expectations.

The occurrence of this conflict can be seen from the possibility of colliding the selfcontrol task of a self-control mechanism owned by a professional with an organizational control mechanism developed by management. The professional attitude of self-sufficiency in solving the problems faced in the execution of their duties will tend to make them "demanding" full control and control over the process or procedure.

\section{Organizational Culture}

According to (J. Peters and H. Waterman, 1982), organizational culture as a pattern of basic assumptions found, created, or developed by a particular group in order that the organization learn to cope or cope with problems arising from external adaptation and internal integration which has been going well enough, so it should be taught to new members as the right way to understand, think and feel about those problems. According to (Hartanto, 2009) Culture can be defined as the totality of the beliefs, attitudes, patterns of behavior, institutional, art, tradition and human mind products that characterize a community within a social environment. Culture is made up of various symbols, rituals, and values, beliefs, ideas, meanings and patterns of behavior that are widely used in everyday life.

(Hartanto, 2009) further defined organizational culture is a system of meaning related to work, work and work interactions that are mutually agreed upon and used in everyday work life. The birth of organizational culture in an organization is a result of the unity of the spirit of cooperation among individual employees by being influenced by the greatest spirit and the strongest individual of one individual in the organization. The strongest spirit is generally the spirit of the organizational leader who will move and influence the spirit of the other individual, then unite in the same rhythm of work.

\section{RESEARCH METHOD}

This research is conducted at Regional Directorate of Taxation of Aceh (DJP Aceh) consisting with research variables are organizational learning, role conflict, organizational culture, employee performance and organizational performance. The population is the office employees as much as 120 people, and the sample is taken by the census method, which takes all population member as a sample, so that is as much as 120 as respondents. Data analysis equipment used in this research is structural equation modeling (SEM) with the help of Amos program. The SEM equation model is a set of statistical techniques that enable the testing of a relatively complex set of relationships simultaneously (Ferdinand, 2002).SEM is able to incorporate latent variables into the analysis. Latent variables are unobserved concepts that are observed with observed or measurable variables obtained by respondents via data collection methods (survey, test, observation) and are often called manifest variables (Ghozali, 2017).

\section{RESULT}

Analysis of data processing result at full stage of SEM model is done by doing conformity test and statistical test. Results of data processing for analysis of full SEM model is 
International Journal of Business Management and Economic Review

Vol. 3, No. 01; 2020

ISSN: 2581-4664

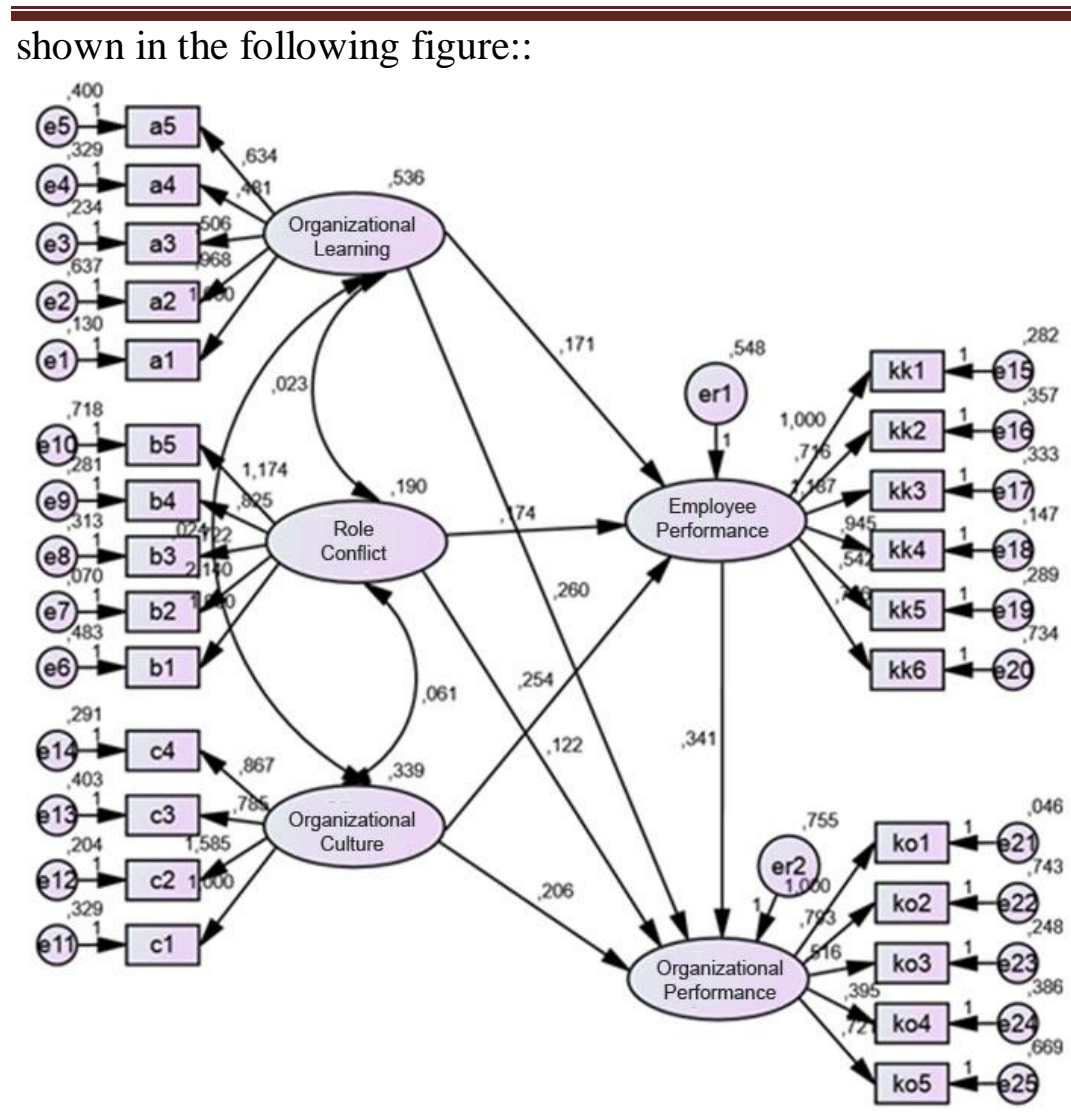

Figure. 1. Structural Equation Model (SEM) Test Result

\section{H1 Is Accepted :The Effect Of Organization learnings On Employee Performance}

Estimation parameters value for testing the effect of organization learning on employee performance shows CR value of 4.315 and with probability of 0.000 . Both values obtained meet the qualification for $\mathrm{H} 1$ acceptance ie $\mathrm{CR}$ value of 4.315 which is greater than 1.97 and probability smaller than 0.05 .

\section{H2 Is Accepted :The Effect Of Role Conflict On Employee Performance}

Estimation value for testing the influence of role conflict on employee performance shows CR value of 3.562 and with probability of 0.000 . Both values obtained meet the qualification for $\mathrm{H} 2$ acceptance ie CR value of 3.562 greater than 1.97 and probability smaller than 0.05 .

\section{H3 Is Accepted :The Effect Of Organizational Culture On Employee Performance}

Estimation parameters value for testing the effect of organizational culture on employee performance shows CR value of 5.026 and with probability of 0.000 . Both values obtained meet the qualification for $\mathrm{H} 3$ acceptance ie $\mathrm{CR}$ value of 5.026 greater than 1.97 and probability smaller than 0.05 .

H4 is accepted :The Effect Of Organizational Learning On Organizational Performance

Estimation parameter values for testing the effect of organization learning on organization 
Vol. 3, No. 01; 2020

ISSN: 2581-4664

performance showed CR value of 3.856 and with probability of 0.000 . Both values obtained meet thequalification for $\mathrm{H} 5$ acceptance ie $\mathrm{CR}$ value of 3.856 greater than 1.97 and probability smaller than 0.05 .

\section{H5 is accepted :The Effect of role conflict on organization performance}

Estimation parameters value for testing the role conflict on organization performance showed CR value of 4.940 and with probability of 0.000 . Both values obtained meet the qualification for $\mathrm{H} 6$ acceptance ie $\mathrm{CR}$ value of 4,940 which is greater than 1.97 and probability smaller than 0.05 .

\section{H6 Is Accepted :The Effect Of Organizational Culture On Organization Performance}

Estimation parameter value for testing of the effect of organization culture on organizational performance shows CR value of 8.839 and with probability of 0.000 . Both values obtained meet the qualification for $\mathrm{H} 7$ acceptance ie CR value of 8.839 greater than 1.97 and probability smaller than 0.05 .

\section{H7 Is Accepted :The Effect Of Employees Performance On Organization Performance}

Estimation parameters value for testing the influence of employee performance on organizational performance showed CR value of 7.343 and with probability of 0.000 . Both values obtained meet thequalificationfor $\mathrm{H} 4$ acceptance ie $\mathrm{CR}$ value of 7.343 which is greater than 1.97 and probability smaller than 0.05 .

\section{CONCLUSION}

The results of the study prove that : organization learning has an effect on employee performance, role conflict has an effect on employee performance, organizational culture has an effect on employee performance, organization learning has an effect on organizational performance, role conflict has an effect on employee performance, organizational culture has an effect on organizational performance, organizational culture has an effect on organizational performance, and employee performance has an effect on organizational performance. These all results contribute to enrich the knowledge especially in management. For academic, this research has tested the model and this can be a reference for further research both in developing or making a new ones. The originality lies in the integration of the previous model and the use of SEM as a statistical approach. The limitation lies in the number of variables that are only five, with one object.

These all findings contribute also to managerial implication both in maping the condition and formulate the solutions. In order to improve the performance of DJP Aceh based on the perspective of organization learning, what needs to be done is to improve the ability of employees to always try to think systematically in order to solve the problem in the office.The role conflict problem that occurs within the organization environment should also be the attention of the leader so that the leader needs to do is to provide support to every employee to develop his human resources through education and training provided by the leadership.Then the improvement of employee performance and organizational performance based on organizational culture, then what needs to be done is that the leader must always devote all his abilities to organizational advancement, by providing himself with various knowledge.In order to improve 


\section{International Journal of Business Management and Economic Review}

Vol. 3, No. 01; 2020

ISSN: 2581-4664

the performance of the DJP of Aceh as a whole, it should be noted that improving the quality of work produced by the employees to obtain approval from the leadership, so employees need to be more careful in the work so that the quality of work can be obtained better.To improve the performance of DJP Aceh, attention needs to be given to ensuring that the implementation of service activities is in accordance with established procedures or not, so that the work can run smoothly, then every officer should always be friendly when providing service to the community, the public is satisfied with the services provided by the employees, so that every job should be made a plan and a job target in such a way that the service provided can provide satisfaction to the community..

\section{REFERENCES}

Argyris, C. and Schon, D. A. (1995) Organizational Learning II: Theory, Method, and Practice. FAC SUB Ed. United States: Addison-Wesley.

Armosudiro, P. (2012) Konsep Organisasi. Jakarta: Raja Grafindo.

Chairy (2011) 'Pengaruh Karakteristik Entrepreneurial, Jenis Etnis, Jenis Kelamin dan Profesi Orang Tua Terhadap Intensi Berwirausaha Mahasiswa', Jurnal Manajemen Bisnis, 1(2), pp. 245-259.

Chaston, I., Badger, B. and Sadler-Smith, E. (1999) 'Organizational Learning: Research Issues and Application in SME Sector Firms', International Journal of Entrepreneurial Behavior \& Research, 5(4), pp. 191-203. doi: https://doi.org/10.1108/13552559910293146.

Engko, C. (2008) 'engaruh Kepuasan Kerja Terhadap Kinerja Individual Dengan Self Esteem dan Self Efficacy Sebagai Variabel Intervening', Jurnal Bisnis dan Akuntans, 10(1).

Fanani, Z., Hanif, R. A. and Subroto, B. (2008) 'Pengaruh Struktur Audit, Konflik Peran, Dan Ketidakjelasan Peran Terhadap Kinerja Auditor', Jurnal Akuntansi dan Keuangan Indonesia, 5(2), pp. 139-155. doi: http://dx.doi.org/10.21002/jaki.2008.07.

Ferdinand, A. (2002) 'Structural equation modeling dalam penelitian manajemen', Semarang: Badan Penerbit Universitas Diponegoro.

Gephart, M. A. et al. (1996) 'Learning Organizations Come Alive', Training \& Development. Available at: https://www.questia.com/magazine/1G1-19045456/learning-organizationscome-alive.

Ghozali, I. (2017) Model Persamaan Struktural, Konsep dan Aplikasi dengan Program AMOS 24 Update Bayesian SEM. Edisi 7. Semarang: Badan Penerbit Universitas Diponegoro.

Hanafi, A. and Widiyanti, M. (2014) 'Pengaruh Kompetensi, Motivasi, dan Kepuasan Kerja Terhadap Prestasi Kerja Karyawan PT. Multi Data Palembang (IT Superstore)', PPM SCHOOL OF MANAGEMENT UNIVERSITAS UDAYANA.

Hartanto, F. M. (2009) Paradigma Baru Manajemen Indonesia: Menciptakan Nilai dengan Bertumpu pada Kebajikan dan Potensi Insani. Bandung: Mizan Pustaka.

Hofstede, G., Hofstede, G. J. and Minkov, M. (2010) Culture and organizations: Software of the mind (Intercultural Cooperationand Its Importancefor Survival). Third Edit. New York: Mc Graw Hill.

J. Peters, T. and H. Waterman, R. (1982) In Search of Excellence: Lessons From America's BestRun Companies. London: Harper Collins Business. doi: 10.2307/2393015.

Khandekar, A. and Sharma, A. (2005) 'Organizational learning in Indian organizations: a strategic HRM perspective', Journal of Small Business and Enterprise Development, 12(2), 


\section{International Journal of Business Management and Economic Review}

Vol. 3, No. 01; 2020

ISSN: $2581-4664$

pp. 211-226. doi: https://doi.org/10.1108/14626000510594610.

Margiati, L. (2010) Pengaruh Kecerdasan Emosi, Karakteristik Individu, Self Leadership, Komitmen Pada Profesi, Iklim Organisasi terhadap Kinerja dan Karier Dosen pada Perguruan Tinggi Swasta Koperti Wilayah VII Jawa Timur. Universitas 17 Agustus 1945, Surabaya.

Maryam, N. S. (2016) 'Mewujudkan good governance melalui pelayanan publik', Jurnal Ilmu Politik dan Komunikasi, VI(1), pp. 1-18.

Money, J. D. (1996) Konsep Pengenbangan Organisasi Publik. Bandung: Sinar Baru Algesindo.

Neefe, D. O. (2001) Comparing levels of organizational learning maturity of colleges and universities participating in traditional and non-traditional (Academic Quality Improvement Project) accreditation processes. University of Wisconsin stout Menomonie, 5.

Pujaningrum, I. and Sabeni, A. (2012) 'Analisis Faktor-Faktor Yang Mempengaruhi Tingkat Penerimaan Auditor Atas Penyimpangan Perilaku Dalam Audit (Studi Empiris Pada Kantor Akuntan Publik Di Semarang)', Dipenogoro Journal of Accounting, 1(1), pp. 870884.

Riyanto, B. and Puspa, D. F. (1999) 'Tipe Lingkungan Pengendalian Organisasi, Orientasi Profesional, Konflik Peran, Kepuasan Kerja dan Kinerja: Suatu Penelitian Empiris', The Indonesian Journal of Accounting Research (IJAR), 2(1). doi: http://doi.org/10.33312/ijar.26.

Stata, R. (1989) 'Organizational Learning -- The Key to Management Innovation', Sloan Management Review, 63(Spring).

Swanburg, R. C., Ester, M. and Samba, S. (2000) Pengantar Kepemimpinan \& Manajemen Keperawatan Untuk Perawat Klinis. Jakarta: Penerbit Buku Kedokteran.

Viator, R., Dalton, D. and Harp, N. (2012) 'How to be a successful mentor: managing challenges, avoiding pitfalls, and recognizing benefits', Human Resource Management International Digest, 20(7). doi: https://doi.org/10.1108/hrmid.2012.04420gaa.010. 